\title{
Studi Kasus: Efek Suplemen Vitamin A dan C pada Perilaku Anak Autism Spectrum Disorder
}

\section{Case Study: The Effect of Vitamin A and C Supplementation to Autism Spectrum Disorder Children Behavior}

\author{
Asmika Madjri', Ibnu Fajar², Rolly Fransisca $\mathrm{H}^{3}$ \\ ${ }^{1}$ Laboratorium Ilmu Kesehatan Masyarakat Faultas Kedokteran Universitas Brawijaya Malang \\ ${ }^{2}$ Politeknik Kesehatan Kemenkes Malang \\ ${ }^{3}$ Program Studi Ilmu Gizi Fakultas Kedokteran Universitas Brawijaya Malang
}

\begin{abstract}
ABSTRAK
Anak Autism Spectrum Disorder (ASD) dengan patologi usus hipersensitifitas terhadap makanan atau leaky gut seringkali menunjukkan defisiensi vitamin dan mineral diantaranya tidak tercukupinya kebutuhan vitamin A dan C dalam jangka waktu yang lama. Salah satu cara penanganan anak ASD adalah dengan memberikan suplemen vitamin A dan C. Penelitian ini bertujuan untuk mengetahui kecenderungan atau pengaruh penggunaan suplemen vitamin $A$ dan $C$ terhadap perilaku anak ASD. Rancangan penelitian yang digunakan adalah case study dengan mengamati perubahan perilaku pada lima kasus ASD yang menggunakan suplemen vitamin A dan C. Penilaian perilaku dilakukan dengan menggunakan Applied Behavioral Analysis. Hasil menunjukkan pada semua kasus menunjukkan konsumsi vitamin $A$ dan $C$ sebagai hasil suplemen vitamin. Pada satu kasus dengan absorbsi vitamin A dan C yang rendah karena kurangnya konsumsi lemak dan protein menunjukkan perilaku yang kurang. Empat kasus lain menunjukkan perilaku yang lebih baik.
\end{abstract}

Kata Kunci: Autism Spectrum Disorder(ASD), perilaku, vitamin A, vitamin C

\section{ABSTRACT}

Clinical laboratory data show that in Autism Spectrum Disease with intestinal pathology hypersensitivity to food or leaky gut often shows a list of long deficiencies of vitamins and minerals such as deficiency in vitamin $A$ and $C$. One way of handling children with ASD is to provide supplements of vitamins $A$ and C. This study aims to identify the effect of vitamin $A$ and C supplement in ASD children's behavior. A case study in 5 ASD cases was performed by measuring the food consumption and observing behavior using Applied Behavioral Analysis. The result shows that all of the cases have high vitamin $A$ and $C$ consumption as the result of supplement. In one case with low vitamin $A$ and $C$ absorption due to low fat and protein consumption show poor behavior. While the other cases (4) show better behavior.

Keywords: Autism Spectrum Disorder (ASD), behavior, vitamin A, vitamin C

Jurnal Kedokteran Brawijaya, Vo. 26, No. 4, Agustus 2011; Korespondensi: Asmika Madjri. Laboratorium Ilmu Kesehatan Masyarakat Fakultas Kedokteran Universitas Brawijaya Malang, Jl. Veteran Malang Tel. (0341) 560491 Email: asmikamadjri@yahoo.com 


\section{PENDAHULUAN}

Masalah penyimpangan perilaku pada anak khususnya autisme menjadi persoalan aktual dan menarik yang ingin diketahui oleh masyarakat baik dari kalangan akademisi maupun masyarakat umumnya (1). Angka kejadian anak autisme masih terus meningkat diseluruh dunia, khususnya di negara-negara Asia apalagi di Indonesia. Di Indonesia pada tahun 1987, ratio penderita autisme 1:5000, ini berarti di antara 5000 anak, ada 1 anak autistik. Angka ini meningkat tajam menjadi $1: 500$ pada tahun 1997, kemudian menjadi 1:100 pada tahun 2008 (2). Hasil penelitian dari Centers for Disease Control and Prevention (CDC) tahun 2012 didapatkan data bahwa terjadi peningkatan 23\% dibandingkan tahun 2008, yaitu 1 dari 100 anak yang menderita autism menjadi 1 dari 88 anak mengalami autisme. dari keseluruhan populasi di dunia. Di Indonesia sendiri belum ada data yang lengkap untuk mengetahui jumlah anak autisme, namun diperkirakan jumlah anak autisme dapat mencapai 150.000-200.000 orang (1).

Pada umumnya, anak dengan Autism Spectrum Disorder (ASD) mengalami malfungsi sistem imun yaitu adanya penurunan sel TH1 dan peningkatan TH2. Hal ini menyebabkan anak ASD cenderung untuk menderita alergi penyakit autoimun dan penurunan fungsi imun secara umum. Keadaan ini dapat mengakibatkan peradangan saluran cerna dan alergi makanan, contohnya bertahannya kuman dan virus di dalam jaringan usus dan kolonisasi yang cukup parah oleh jamur atau bakteri patogen, sehingga anak ASD mengalami gangguan pada masalah perilaku yaitu sulit kosentrasi, hiperaktif, rentang perhatian yang singkat, lekas marah dan agresif (3). Hal senada juga diungkapkan, bahwa anak ASD memiliki fungsi imunitas yang menurun, misalnya pada anak dengan alergi makanan (4).

Munurut McCandless banyaknya spesies jamur di dalam saluran cerna meningkatkan produksi racun. Salah satu dari racun ini adalah enzim yang menghasilkan lubang di dinding usus yang dapat mengakibatkan terjadinya suatu keadaan yang disebut leaky gut. Keadaan ini menyebabkan anak ASD selalu mengalami maldigesti dan malabsorbsi yang memperparah rusaknya kesadaran, kemampuan kognitif, kemampuan bicara atau tingkah laku.

Data klinis laboratorium anak-anak ASD dengan patologi usus hipersensitifitas terhadap makanan atau leaky gut seringkali menunjukkan defisiensi berbagai vitamin dan mineral yang lama. Diantara daftar defisiensi tersebut adalah defisiensi vitamin $\mathrm{A}$ dan $\mathrm{C}$ dalam jangka waktu lama (3). Selektivitas makanan penting bagi anak-anak dengan ASD. Asupan protein, vitamin A, vitamin C, besi, vitamin D, thiamin,vitamin B-12, asam folat, natrium, kalium, magnesium,fosfor, dan tembaga yang memadai sangat dibutuhkan untuk penanganan anak dengan ASD.

Vitamin A dan C sangat penting dalam menopang fungsi tubuh terutama memperkuat imun sistem dan reaksi metabolik lainnya di dalam tubuh, (5). Kelley dalam penelitiannya pada pria perokok menemukan bahwa, penurunan konsumsi vitamin A dari $250 \mathrm{mg}, 5,10$, atau 20 $\mathrm{mg} /$ hari selama 60 hari tidak menyebabkan proliferasi limfosit dan DTH namun respon akan meningkat jika intake vitamin C ditingkatkan menjadi $60 \mathrm{mg} /$ hari sampai
$250 \mathrm{mg} /$ hari selama 3 minggu (6).

Pada anak ASD yang telah dilakukan di pusat terapi A plus Malang menunjukkan bahwa sebanyak 59\% anak ASD dari 17 anak menggunakan suplemen. Suplemen yang digunakan mengandung berbagai vitamin seperti vitamin A, B complex, C, D, E, dan $\mathrm{K}$ dan mineral seperti magnesium, zinc, iodium, selenium, kalsium, mangan dan molibdenium. Suplemen yang paling sering direkomendasikan dan dipakai oleh orang tua anak ASD di pusat terapi A plus Malang adalah vitamin A dan C berdasarkan petunjuk dan nasehat dokter. Penelitian ini dilakukan untuk mengidentifikasi efek suplemen vitamin A dan C pada perubahan perilaku anak ASD di Pusat Terapi A plus Malang.

\section{METODE}

Penelitian dilakukan dengan desain case study pada siswa ASD di Pusat Terapi A plus Kota Malang. Sampel dipilih dengan kriteria telah ditegakkan diagnosis oleh dokter sebagai ASD, dan menggunakan suplemen vit $A$ dan $C$. Jumlah seluruh siswa adalah 17 anak dengan 5 anak belum menggunakan suplemen vit $A$ dan $C$ juga belum pernah berkonsultasi dengan dokter, 5 anak lainnya menggunakan probiotik dan mineral lain, sedangkan 2 anak lainnya didiagnosa dengan penyakit bawaan yaitu dengan cerebral palsi dan retardasi mental, sehingga didapatkan 5 kasus untuk diamati. Data yang dikumpulkan adalah 1) data konsumsi makan selama 24 jam dengan menggunakan metode estimated food record non consecutive day dan 2) data perilaku dari formulir penilaian metode Applied Behavior Analysis (ABA).

\section{HASIL}

\section{Gambaran Karakteristik Subjek}

Sebagian besar responden yaitu sebanyak 3 orang dari 5 orang responden dalam penelitian ini berjenis kelamin laki-laki dan sisanya (2 orang) berjenis kelamin perempuan. Seluruh responden berusia kurang dari 14 tahun dengan 3 responden (60\%) berusia kurang dari 10 tahun (Tabel 1). Berdasarkan jenis autisme, 3 orang didiagnosa sebagai autisme dengan 1 orang spektrum autis dan 1 orang Attention Deficit and Hiperactivity Disorder (ADHD). Pada semua kasus gejala autisme sudah muncul sejak usia tiga tahun, termasuk pada satu responden yang berusia tiga tahun gejala autisme diketahui sejak 8 bulan yang lalu. Sebagian besar responden yaitu sebanyak 3 orang dari 5 responden mengalami mempunyai alergi makanan dan 2 orang responden tidak mengalami mempunyai riawayat alergi makanan. Bahan makanan yang dapat memicu timbulnya alergi bagi responden 1 adalah tepung terigu, daging, udang, kerang, telur, ikan laut, kubis, daun singkong, pisang, jeruk, mangga, apel, susu sapi, susu skim, susu kedelai, kacang tanah, dan kedelai. Bahan makanan yang dapat memicu timbulnya alergi bagi responden 2 adalah susu sapi dan ikan laut sedangkan bagi responden 5 adalah kangkung dan apel berdasarkan pengakuan orang tua responden dengan melihat perilaku sesudah mengkonsumsi. Semua responden diberikan suplemen vitamin dengan dosis sama, dengan lama penggunaan 1 bulan (2 orang), 6 bulan (2 orang), dan 1 tahun (1 orang). 


\section{Tabel 1. Gambaran karakteristik subjek penelitian}

\begin{tabular}{cc}
\hline Karakteristik & Jumlah (n=5) \\
\hline Jenis kelamin & 3 \\
$\square \quad$ Lelaki & 2 \\
$\square \quad$ Perempuan & \\
Usia (tahun) & 2 \\
$\square \quad 3$ & 1 \\
$\square \quad 4$ & 1 \\
$\square \quad 11$ & 1 \\
$\square \quad 13$ & \\
Jenis ASD & 3 \\
$\square \quad$ Autisme & 1 \\
$\square \quad$ Spektrum autis & ADHD \\
$\square \quad$ Ada & 1 \\
Riwayat alergi & 3 \\
$\square \quad$ Tidak ada & 2 \\
\hline
\end{tabular}

\section{Hubungan Tingkat Konsumsi Vitamin A, Lemak, Protein,} dan Vitamin C dengan Perilaku

Pemberian suplemen vitamin A pada hasil evaluasi memberikan tingkat konsumsi vitamin $\mathrm{A}$ dan $\mathrm{C}$ yang lebih (jumlah asupan dibandingkan kebutuhan dengan skor $>100 \%$ dari AKG) pada semua kasus. Dalam penyerapan dan mobilisasi vitamin $A$ di dalam tubuh, vitamin $A$ membutuhkan peran serta dari lemak dan protein. Dari lima kasus terdapat 1 kasus yang memiliki tingkat konsumsi lemak dan protein kurang dan 4 kasus dengan konsumsi baik (lemak) atau lebih (protein).

Perilaku responden dilihat dari penilaian terhadap pencapaian 4 kemampuan yaitu: kemampuan siap diri, kemampuan meniru, kemampuan berbahasa, dan kemampuan bantu diri. Hasil penelitian menunjukkan sebanyak 1 orang dari 5 responden yaitu responden 5 masih dalam kategori kurang, responden 1 dan 2 dalam kategori sedang dan 2 orang responden lainnya yaitu responden 3 dan 4 dalam kategori baik berdasar formulir penilaian metode Applied Behavior Analysis. Dapat disimpulkan bahwa pada lima kasus dengan pemberian suplemen vitamin A dan C memberikan tingkat konsumsi yang lebih dan sebagian besar memberikan perilaku sedang hingga baik (4 orang) dan hanya 1 yang masih menunjukkan perilaku kurang. Pada responden dengan perilaku yang kurang ini meskipun tingkat konsumsi vitamin A dan C sudah melebih AKG, namun kurang dalam konsumsi lemak dan protein.

\section{DISKUSI}

Gambaran Jenis Kelamin, Usia, Jenis Autisme, dan Riwayat Alergi

Dari lima responden dalam penelitian ini, 3 orang laki-laki dan 2 lainnnya perempuan, dengan usia dalam rentang 313 tahun. Dari kelima responden, diketahui ada 3 responden yang memiliki riwayat alergi terhadap makanan tertentu. Tingginya jumlah responden penelitian ini yang berjenis kelamin laki-laki dimungkinkan oleh adanya faktor genetik, faktor genetik yang juga berpengaruh kromosom terutama pada kromosom sex $\mathrm{X}$. Hasil penelitian membuktikan bahwa gen tertentu pada kromosom $X$ dapat berpengaruh terhadap kemampuan interaksi sosial. Kromosom $X$ dan $Y$ berperan dalam determinasi seks individu. Seorang pria mempunyai satu kromosom $X$ dan satu kromosom $Y$ sedangkan wanita mempunyai dua kromosom $X$. Bila ada gen yang tidak bekerja dengan baik pada salah satu kromosom $X$ pada wanita maka gen pada kromosom $X$ kedua dapat menggantikannya. Hal ini tidak terjadi pada pria karena mereka hanya mempunyai satu kromosom X. Ketiadaan kromosom cadangan menjelaskan mengapa beberapa kelainan yang dikenal sebagai kelainan terpaut $X$ umumnya terjadi pada pria (7).

Rentang usia pada responden dalam penelitian ini memang jauh berbeda yaitu dari responden yang berusia 3 tahun, 4 tahun, sampai yang berusia 11 dan 13 tahun. Perbedaan rentang usia yang jauh pada responden penelitian ini tidak mempengaruhi adanya perbedaan pola kematangan perkembangan atau perilaku seperti yang terdapat pada anak yang normal pada umumnya. Anak dengan Autism Spectrum Disorder (ASD) sangat berbeda jika dibandingkan dengan anak yang normal walaupun dalam usia yang sama, kemampuan anak ASD bisa jauh dibawah dari anak yang normal.

Keadaan ini sesuai dengan pernyataan Maulana bahwa pada usia 2-5 tahun anak ASD cenderung memiliki kebiasaan yang sangat buruk. Ketika menginjak usia 6-10 tahun, perilaku mereka akan membaik, tetapi, perilaku itu akan cenderung memburuk kembali saat mereka memasuki usia remaja serta dewasa. Selanjutnya perilaku akan membaik seiring dengan bertambah tuanya usia mereka. Hal ini semua juga dipengaruhi oleh rutinnya terapi yang mereka jalani.

Dalam penelitian ini jenis autisme yang diderita responden adalah dalam bentuk kolektif sebagai Autism Spectrum Disorder (ASD). Sebagaimana yang sudah dijelaskan, bentuk-bentuk gangguan perkembangan yang diasosiasikan dengan autis adalah Attention Deficit Hyperactivity Disorder (ADHD), Attention Deficit Disorder (ADD), Pervasive Development Disorder (PDD), dan sindrom asperger (8).

Dalam penelitian ini sebagian besar responden yaitu 3 orang dari 5 orang responden menderita alergi makanan. Makanan dapat berperan ganda, selain dapat menyediakan zat- zat gizi yang dibutuhkan bagi anak ASD, di sisi lain makanan dapat menjadi pemicu timbulnya berbagai penyakit atau alergi makanan, beberapa jenis bahan makanan yang dikonsumsi dapat memperburuk kondisi penderita autisme. Adanya riwayat alergi terhadap makanan ini, merupakan suatu tanda adanya ketidakmampuan anak ASD untuk mencerna gluten dan kasein, dan adanya infeksi jamur kronis merupakan petunjuk terjadinya kerusakan imun tubuh. Keadaan pada responden dalam penelitian ini sesuai dengan pernyataan penelitian sebelumnya, bahwa banyak anak penderita autisme, mempunyai semacam imun yang malfungsi. Seringkali kerusakan fungsi ini menyebabkan tubuh salah mengidentifikasi sel-sel diri sendiri (self) dan menduganya sebagai molekul asing (foreign), padahal bukan. Pada tipe disfungsi imun seperti ini, sistem imun tubuh akan menyerang tubuh itu sendiri (3).

Penggunaan Suplemen Vitamin A dan C dalam Terapi ASD dan Efeknya pada Perilaku

Suplemen vitamin A dan vitamin C yang diberikan dikemas dalam bentuk yang mudah larut dalam saluran pencernaan. Vitamin A pada suplemen dalam bentuk utuh carotenoid, dengan 40-60\% carotenoid akan diserap langsung oleh saluran pencernaan. Vitamin C pada 
suplemen sudah dalam bentuk buffered (campuran bentuk asam dan garamnya), atau terestifikasi. Bentuk ini sangat menguntungkan untuk mengurangi pengaruh keasaman pada vitamin $\mathrm{C}$ biasa dengan dosis tinggi dan juga dapat dilakukan dengan cara membagi dosisnya, seperti yang dilakukan oleh orang tua responden dan atas saran dokter yaitu membagi dosisnya menjadi $1 / 4$ tablet dalam satu hari. Vitamin C yang biasa dalam kadar tinggi dapat menyebabkan efek gangguan lambung, hanya diserap sebagain dan cepat dibuang tubuh. Ester-C atau bentuk buffered memperbaiki semua kelemahan tersebut. Tidak menganggu lambung, diserap lebih cepat, serta lebih lama bertahan di dalam tubuh (9).

Penggunaan suplemen vitamin A dan $\mathrm{C}$ ini berdasarkan atas saran dari dokter untuk memperkuat sistem imun. Kekurangan vitamin A dan C akan mengakibatkan anak (subjek) mudah terserang penyakit, cengeng, mudah marah, nyeri tungkai bawah, lelah dan perdarahan kulit (10). Kekurangan vitamin A dan C juga mempengaruhi serangkaian fungsi termasuk pertumbuhan, imun tubuh, dan perkembangan otak (3). Semba menyatakan bahwa vitamin A mengatur banyak aspek yang berbeda dari fungsi sistem imun, termasuk dari kedua komponen imun spesifik dan non-spesifik (11).

Penggunaan suplemen vitamin A berperan sebagai antioksidan dan meningkatkan imun tubuh, mencegah pilek, influenza, dan infeksi. Vitamin A juga penting dalam membantu tubuh memanfaatkan protein (3). Kebanyakan anak ASD biasanya tidak mengkonsumsi banyak makanan yang mengandung vitamin $A$ alamiah, sehingga diperlukan suplementasi. Vitamin A dalam dosis besar juga bisa menjadi racun, namun peristiwa ini jarang terjadi karena beta-karotin diubah menjadi vitamin A di hati dan tidak bisa menjadi overdosis.

Dalam penyerapan dan mobilisasi vitamin A di dalam tubuh, vitamin A membutuhkan peran serta dari lemak dan protein. Tingkat konsumsi lemak dan protein responden dalam penelitian ini masih ada yang tergolong dalam kategori kurang (responden 5), hal ini dikarenakan oleh responden mengalami susah makan dan jumlah bahan makanan yang dikonsumsi masih belum memenuhi Angka Kecukupan Gizi (AKG), sehingga asupan suplemen vitamin $\mathrm{A}$ dan $\mathrm{C}$ responden 5 dimungkinkan tidak terserap secara sempurna di dalam tubuh. Data menunjukkan pada 1 kasus 5 memiliki perilaku dalam kategori kurang, walau tingkat konsumsi dari vitamin A dalam kategori lebih, hal ini disebabkan oleh adanya pengaruh dari tingkat konsumsi dari lemak dan protein responden yang masih dalam kategori kurang sehingga dimungkinkan vitamin $A$ yang dikonsumsi sebagai suplemen dan vitamin A lain dari bahan makanan tidak dapat diserap dan dimobilisasi secara baik dalam tubuh responden.

Lemak berfungsi dalam transportasi vitamin larut lemak termasuk vitamin A. Penyerapan vitamin A terjadi di usus halus manusia merupakan proses aktif yang membutuhkan energi. Energi ini berasal dari fosforilasi oksidatif. Di dalam usus halus terjadi re-esterifikasi dengan asam lemak rantai panjang (12).

Lemak berfungsi sebagai alat angkut vitamin larut lemak termasuk vitamin A. Retinol di dalam mukosa usus halus bereaksi dengan asam lemak dan membentuk ester dan dengan cairan empedu menyeberangi sel-sel vili dinding usus halus untuk kemudian diangkut oleh kilomikron melalui sistem limfe ke dalam aliran darah menuju hati
(13). Dengan konsumsi lemak yang cukup, sekitar $80-90 \%$ ester retinil dan 40-60\% karotenoid akan diabsorbsi oleh tubuh.

Fungsi dari protein dalam absorbsi vitamin $A$ adalah sebagai alat angkut vitamin $A$ dari hati ke tempat yang membutuhkan vitamin A (13). Bila tubuh memerlukan, vitamin A dimobilisasi dari hati dalam bentuk retinol yang diangkut oleh Retinol Binding-Protein (RBP) yang disintesis di dalam hati. Pengambilan retinol oleh berbagai sel tubuh bergantung pada reseptor pada permukaan membran yang spesifik untuk RBP. Retinol kemudian diangkut melalui membran sel untuk kemudian diikatkan pada Cellular Retinol Binding-Protein (CRBP) dan RBP kemudian dilepaskan.

Gangguan atau peradangan saluran cerna akibat adanya alergi makanan yang diderita oleh anak ASD dapat bermanifestasi pada gangguan perilaku anak ASD. Selain adanya peradangan saluran cerna atau alergi makanan, adanya gangguan nutrisi terutama vitamin $A$ dan $C$ di seluruh sistem tubuh pada anak dengan ASD dapat menyebabkan banyaknya ketidakmampuan untuk bersosialisasi,sulitnya untuk berkosentrasi dan memperhatikan tugas yang sedang dikerjakan. Anak ASD hampir selalu memiliki penyimpangan kesehatan fisik dan menyebabkan tubuh mengalami distrub biochemichal homeostasis atau ketidakseimbangan yang menyebabkan gangguan nutrisi di seluruh sistem tubuh, termasuk otak (3).

Pemberian suplemen vitamin A pada responden ini dapat membantu memperkuat imunitas tubuh pasien sehingga mengurangi reaksi alergi akibat adanya leaky gut pada saluran cerna pasien sehingga dapat dilihat dengan adanya perbaikan perilaku responden. Keadaan ini didukung oleh hasil penelitian Megson dalam buku Mc. Clandess, yang telah menggunakan vitamin A bentuk cis alami yang ditemukan pada cod liver oil untuk anak ASD bersama dengan stimulasi reseptor asetilkolin yang terhambat lewat penggunaan urokolin (betanikol) untuk meningkatkan sekresi empedu dan pankreas. Dengan pemberian cod liver oil (5000 IU/hari) selama beberapa minggu. Betanekol akan membantu menyambungkan kembali jalan reseptor retinoid untuk pengelihatan, persepsi, sensorik, pengolahan bahasa, dan perhatian (3).

Curtis dan Patel menyatakan hal serupa, bahwa untuk mengatasi penyakit tertentu seperti infeksi atau peradangan digunakan dalam dosis tinggi 5000 IU sehari selama infeksi, tetapi tidak lebih dari satu bulan pemakaian (9). Penggunaan suplemen vitamin A dalam dosis tinggi tidak boleh digunakan dalam jangka waktu satu bulan (lebih dari satu bulan atau dua bulan), karena vitamin A yang larut dalam lemak disimpan dalam jaringan tubuh. Bahwa vitamin A dalam dosis besar juga bisa menjadi racun, namun peristiwa ini jarang terjadi karena beta-karotin diubah menjadi vitamin A di hati dan tidak bisa menjadi overdosis.

Jenis suplemen vitamin C yang disarankan oleh dokter merupakan bentuk vitamin $\mathrm{C}$ yang mudah diserap dengan dosis yang sama dan lama penggunaan yang berbedabeda pada masing-masing responden tergantung diagnosa yang diberikan oleh dokter, jika dikaitkan dengan perilaku terdapat 2 responden yang memiliki perilaku yang baik dan 2 responden lainnya memiliki perilaku yang dalam kategori sedang. Dari hasil penelitian yang dilakukan selama 1 bulan ini terlihat adanya 
kecenderungan atau pengaruh pemberian suplemen vitamin C terhadap perilaku responden.

Penggunaan suplemen vitamin $\mathrm{C}$ ini diharapkan selain dapat meningkatkan daya tahan tubuh juga dapat memperbaiki perilaku anak ASD. Vitamin $\mathrm{C}$ adalah antioksidan penting bagi anak ASD yang bekerja untuk melawan radikal bebas. Radikal bebas adalah suatu molekul oksigen tidak stabil yang dapat menembus dinding sel dan mengoksidasi atau menghancurkan sel-sel otak (3). Karena sel-sel otak sangat rentan terhadap stres yang oksidatif, maka penting sekali terdapat persediaan cukup vitamin C. Vitamin C Juga sangat penting untuk fungsi otak, tapi tidak diproduksi sendiri melainkan dari dari diet atau melalui suplemen. Vitamin C diketahui dapat meningkatkan kognisi, fungsi mental dan daya ingat, sedangkan penurunan depresi, kebingungan dan pikiran berkabut. Hal ini meningkatkan imunitas, membersihkan tubuh dari radikal bebas dan melindungi sel dari kerusakan.

Vitamin C juga dapat meningkatkan daya tahan tubuh terhadap berbagai macam penyakit, termasuk gangguan menular. Vitamin C melindungi sistem kekebalan tubuh dengan merangsang aktivitas antibodi dan sel-sel sistem kekebalan tubuh dan melindungi terhadap kerusakan oleh radikal bebas yang dikeluarkan oleh tubuh dalam melawan resiko infeksi. Sebagai konstituen dari kolagen, vitamin C meningkatkan kekebalan kulit dalam melawan bakteri pathogen. Hal ini juga merangsang produksi dari PGE 1 (prostaglandin), membantu limfosit dalam sel darah putih mempertahankan sistem kekebalan tubuh dari kuman penyerang. Fungsi lain dari vitamin $C$ adalah sebagai penghasil senyawa transmiter saraf dan hormon tertentu, membantu memperbaiki sel tubuh dan meningkatkan kerja enzim sebagai faktor penyerap dan pengguna zat gizi lainnya. Vitamin C adalah vitamin esensial, karena manusia tidak dapat mengasilkan vitamin C sendiri, sehingga diperlukan asupan vitamin $\mathrm{C}$ dari makanan atau suplemen. Pada saat mengalami infeksi, dibutuhkan vitamin $C$ dalam jumlah yang sangat besar untuk membantu darah putih menghancurkan kuman penyerang (14).

Satu studi menunjukkan anak-anak dengan autisme memiliki stres oksidatif yang signifikan, sehingga suplementasi dengan antioksidan terbukti, seperti vitamin $C$, yang membantu dalam memerangi radikal bebas (12). Vitamin C juga mengangkat tingkat glutathione, antioksidan lain yang penting dalam tubuh. Menurut data dari Autism Research Institute, B:W rasio (lebih baik: lebih buruk dengan pengobatan) dilaporkan oleh orang tua dari anak-anak autis untuk vitamin Cadalah 16:01.

\section{DAFTAR PUSTAKA}

1. Judarwanto W. Alergi Makanan dan Autisme. (Online) 2000. http://www.fik.ui.ac.id/pkko/files/ ALERGI\%20MAKANAN\%20DAN\%20AUTISME\%20yay an.doc [diakses 10 April 2008].

2. Sun $X$ and Allison C. A review of the prevalence of Autism Spectrum Disorder in Asia. Research in Autism Spectrum Disorders. 2010; 4(2): 156-167.

3. McCandless J. Children with Starving Brains: A Medical Treatment Guide for Autism Spectrum Disorder. 4th edition. Wilton Manors, Florida:
Pemberian suplemen vitamin $\mathrm{C}$ pada responden membantu memperkuat imunitas tubuh pasien sehingga mengurangi reaksi alergi akibat adanya leaky gut pada saluran cerna pasien sehingga dapat dilihat dengan adanya perbaikan perilaku responden. Keadaan ini didukung oleh hasil penelitian pada 12 anak ASD menunjukkan bahwa pemberian suplemen vitamin $C$ dapat meningkatkan score total dari motorik kasar yang diukur dengan ritro-freeman real life rating scale (15). Penelitian lain yang mendukung yaitu menurut penelitian yang dilakukan pada 12 orang pria sehat menyatakan bahwa defesiensi vitamin C tidak menimbulkan efek proliferasi dari Peripheral blood mononuclear cells (PBMNC) yang terdiri dari sel B dan sel T mitogen. Pada keadaan yang sama, konsumsi vitamin $C$ yang kurang menunjukkan penurunan secara nyata dari respon Delayed Hypersensitivity Skin (DHS), dengan kata lain dalam keadan defesiensi vitamin C seseorang lebih hipersensitif (16).

Peningkatan konsumsi vitamin C sebanyak 10 sampai 20 mg per hari tidak bisa meningkatkan fungsi imun tubuh. Peningkatan konsumsi vitamin C sebanyak 60 sampai 250 mg selama 28 hari per hari belum bisa meningkatkan proliferasi dari Peripheral blood mononuclear cells (PBMNC) akan tetapi dapat meningkatkan respon Delayed Hypersensitivity Skin (DHS). Peningkatan konsumsi vitamin $\mathrm{C}$ dapat menyediakan peran immunofarmakologi yang bermanfaat dalam tubuh. Hal ini diperkuat dalam pernyataan Kelley, penurunan konsumsi dari $250 \mathrm{mg}, 5$, 10, atau $20 \mathrm{mg} /$ hari selama 60 hari tidak menyebabkan proliferasi limfosit. Respon akan meningkat jika intake vitamin C ditingkatkan menjadi $60 \mathrm{mg} /$ hari sampai 250 $\mathrm{mg} /$ hari selama 3 minggu. Pernyataan yang sedikit berbeda diungkapkan oleh penelitian sebelumnya bahwa vitamin $\mathrm{C}$ menunjukkan peran dalam menstimulasi imun sistem melalui merangsang proliferasi Sel $\mathrm{T}$ dalam merespon infeksi. Sel T ini memiliki kemampuan untuk melisis target yang terinfeksi dengan memproduksi sejumlah besar sitokin dan membantu sel B dalam mensistesa immunoglobulin untuk mengontrol reaksi inflamasi dan Vitamin C juga mencegah terjadi apoptosis dari sel T (17).

Hasil penelitian ini menunjukkan bahwa pada kasus dengan tingkat penyerapan vitamin A dan $\mathrm{C}$ yang kurang meskipun dengan konsumsi yang lebih akibat pemberian suplemen vitamin memberikan gambaran perilaku yang kurang. Studi lebih luas diperlukan untuk mengkaji efek pemberian suplemen, efektifitas penyerapan dan dampaknya pada perubahan perilaku ASD.

Bramble Books; 2009.

4. Levy SE, Mandell DS, and Schultz RT. Autism. The Lancet. 2009; 374: 1627-1638.

5. Gropper SS and Smith JL. Advance Nutrition and Human Metabolism. 6th edition. Belmont: Wadsworth Cengage Learning; 2009.

6. Kelley DS and Bendich A. Essential Nutrients and Immunologic Functions. The American Journal of Clinical Nutrition. 1996; 63(6): 994-996.

7. Jamain S, Quach H, Betancur C, et al. Mutations of the X-linked Genes Encoding Neuroligins NLGN3 and 
NLGN4 are Associated with Autism. Nature Genetics. 2003; 34: 27-29.

8. Zahar G. Metoda Balur Detoksifikasi Logam dan Radikal Bebas untuk Anak Autis Tanpa Diet. Jakarta: Perhimpunan Seminat Peluluh Radikal Bebas (PSPRB); 2004.

9. Curtis LT and Patel K. Nutritional and Environmental Approaches to Preventing and Treating Autism and Attention Deficit Hyperactivity Disorder (ADHD). The Journal of Alternative and Complementary Medicine. 2008; 14(1): 79-85.

10. Maulana M. Anak Autis "Mendidik Anak Autis dan Gangguan Mental Lain Menuju Anak Cerdas dan Sehat". Edisi ke 2. Jogjakarta: Katahati; 2008.

11. Ebstein RP, Mankuta D, Yirmiya N, and Malavasi F. Are Retinoids Potential Therapeutic Agents in Disorders of Social Cognition Including Autism? FEBS Letters. 2011; 585(11): 1529-1536

12. Kaplan BJ, Fisher JE, Crawford SG, Field CJ, and Kolb B. Case Report: Improved Mood and Behavior During
Treatment with a Mineral-Vitamin Supplement: An Open-Label Case Series of Children. Journal of Child and Adolescent Psychopharmacology. 2004; 14(1): 115-122.

13. Mahan LK and Escott-Stump S. Food Nutrition and Diet Therapy. 11th edition. Philadelphia: WB Saunders Company; 2004.

14. Iqbal K, Khan A, and Khattak MMAK. Biological Significance of Ascorbic Acid (Vitamin C) in Human Health. Pakistan Journal of Nutrition. 2004; 3(1): 5-13.

15. Myers S and Johnson CP. Management of Children with Autism Spectrum Disorders. Pediatrics. 2007; 120(5): 1162-1182.

16. Jacob RA, Kelley DS, Pianalto FS, et al. Immunocompetence and Oxidant Defense During. The American Journal of Clinical Nutrition. 1991; 54(6): 1302-1309.

17. Campbell JD, Cole M, Bunditrutavorn B, and Vell AT. Ascorbic Acid is a Potent Inhibitor of Various Forms of $T$ Cell Apoptosis. Cellular Immunology. 1999; 194(1): 1-5. 